Omni-Akuatika, 14 (2) : 86-90,2018
ISSN: 1858-3873 print / 2476-9347 online
Research Article
journal homepage: http://ojs.omniaquatika.net

\title{
Effect of Variant Manure on Generation Time in Daphnia sp.
}

\author{
Herman Hamdani $^{1^{*}}$, Asep Sahidin ${ }^{1,2}$, Taufiq Hidayat $^{3}$ \\ ${ }^{1}$ Department of Fisheries, Faculty of Fisheries and Marine Science, Universitas Padjadjaran, Indonesia \\ ${ }^{2}$ Laboratory of Aquatic Resources, Faculty of Fisheries and Marine Science, Universitas Padjadjaran, Indonesia \\ ${ }^{3}$ PT Mina Maritim Indonesia, Indonesia
}

*Corresponding autor: Hamdani herman@yahoo.com

\begin{abstract}
The research about generation times of Daphnia sp. was carried out on Mei - June 2017 in Biology Laboratory, FPIK UNPAD. The objective of this research was to analyse the generation time of Daphnia sp. in different manure. The research used experimental method Randomized Completely Block Design (RCBD) with four treatment and three replication. The variant of manure as treatment were chicken manure $(A)$, quail manure $(B)$, cow manure $(C)$, and goat manure $(D)$. The weight for each manure media as many as $2,4 \mathrm{~g} / \mathrm{l}$ in 1 litre of glass media. The best performance of life table distribution showed from the cow manure, but quail manure treatment give the best of all biological factor, it mean that Daphnias were cultured with quail manure have good performance in biological parameter.
\end{abstract}

Keywords : Daphnia culture, generation times,

\section{Introduction}

Rapid advancement of fisheries sector also give impact for the resources management, technology, and knowledge. The one of the most potent resources is Daphnia $\mathrm{sp}$. as the part of zooplankton. Daphnia plays a central role as an energy transfer between producer and secondary consumer in the food webs of the aquatic ecosystem (Kim. et al, 2017) and also used to be natural feed for aquaculture.

Natural feed brings risks for bioaccumulation (Celia et al. 2000) such as pesticide, heavy metals, and their mixtures (Mansour, 2015). The best effort to get the great of natural feed is manipulating the environtment like the native habitat and good nutrition supported (Prastya et al. 2016). Artemia sp. is an example for the best of natural feed in aquaculture. In reality, Artemia $\mathrm{sp}$. has expensive price and difficult to culture particularly for fish farmer from Indonesia. Daphnia sp. is the best natural feed for tropical fry fish and also has potential to be an alternative to subtitute Artemia sp. function as natural feed.

The high reproduction rate, the ease of culturing, the accessibility to experimental manipulation, and the potential to applu sophisticated measuring thechniques such as flow cytometry render some ciliate species ideal candidates for ecophysiological laboratory experiment (Weisse, 2006).

Daphnia sp. is the potential of natural feed source to develop for aquaculture (Mubarak et al. 2009). Another strengths of culturing Daphnia sp. are sterile assured, free from diseases, also guaranteed quality and continuity because stocking Daphnia sp. into culture media will not make water quality stress (Darmawan 2014).

Nutrient for Daphnia sp. culture obteined from manure in media. Decomposition from manure will growth bacteria, and the bacteria will be a feed source for Daphnia sp. (Shigang 1985). Ammonia is the first substance from organic matter decomposition. Ammonia devided into un-ionized ammonia $\left(\mathrm{NH}_{3}\right)$, and ionized ammonia $\left(\mathrm{NH}_{4}{ }^{+}\right)$. Ammonia in water will more toxic with $\mathrm{pH}$ increase (Xiang. et al, 2010).

Generation time in particular, is a lifehistory or period from the laying of an egg to the time the individual which develops from that egg reaches sexual maturity. Generation time in the single most important determinant of the rate of population growth in species and thus (Gillooly, 2000). Daphnia sp species and another microcrustacean give short of 
generation time with high population (Pietrzak, 2011).

Variation in the time spent in each life history of Daphnia has often been explained as species-specific adaptations to environtment condition, but the information about variant manure for Daphnia culture is seldomly found. Herman et al (2018) showed that if quail manure is the best organic manure for Daphnia culture and give the best performance of life history between growth rate, natality rate, and mortality rate, but the generation time was not analyse yet.

The objective of this research was to analyse the generation time as biological factor of Daphnia with using different manure media.

\section{Material and Method}

The research consist of preparation, kohort culture, and main research. This research used experimental method by using Randomized Completely Block Design (RCBD) with four treatment and three replication. The treatments in this research are the variant manures from chicken, quail, goat, and cow with same growth $(2,4 \mathrm{~g} / \mathrm{l})$. This research analysed the primary datas consist of :

1. The number of parent of Daphnia sp. on the time- $x_{i}\left(K U-x_{i}\right)$

2. The number of natality of neonets from female on the time- $x_{i}\left(K U-x_{i}\right)$

3. The number of death Daphnia sp. on the time- $x_{i}\left(K U-x_{i}\right)$

4. Water quality (temperature, $\mathrm{pH}, \mathrm{DO}$, ammonia)

Growth rate, net reproduction rate (Ro), generation times $(\mathrm{Tc})$, natality rate, and mortality rate were calculated by formula from Lotta (1913) in Ocampo et al. (2012) :

$$
\begin{gathered}
\text { Ro }=\sum_{x=0}^{n} l_{x} m_{x} \\
\operatorname{Tr}=1 / R_{0} \sum_{x=0}^{n} x \cdot l_{x} \cdot m_{x} \\
e^{7-m x} l x \cdot m x=1097 \\
1 / \beta=L x \cdot e^{-r(x+1)} \\
b=\frac{r \beta}{e^{m}-1}
\end{gathered}
$$

$$
d=b-r
$$

Note:

$\mathrm{TC}=$ generation times (days)

Ro $=$ net reproduction rate

$r=$ growth rate

$\mathrm{IX}=$ the number of individu after standarization (survival time specific)

$\mathrm{Lx}=$ average of individu in $\mathrm{KU}-\mathrm{x}$ and $\mathrm{KU}-\mathrm{x}+1$

$\mathrm{mx}=$ the number of neonet in specific time

$x=$ time of culture

$\mathrm{b}=$ natality rate

$\mathrm{d}=$ mortality rate

There were two preparation for this research. First, manure should be dried without water contained. After that, manure weighed amount 2,4 gram. Next, the manure should be wraped and tied.. Futhermore, one liter water put in a container and installed it on the aeration set. The wraped manure entered, and the media aerated for 3 days.

Mature Daphnia sp.(F0) cultured in a media culture for 1 day. The new neonets (F1) would be present, and took the neonets (F1) to the other media culture. The new neonets $(F 1)$ cultured until adult and made a new generation (F2). The new generation (F2) used for the main research.

Second generation (F2) of Daphnia sp. entered in every treatment amount 100 individu/l. Daphnia (F2) counted everyday and moved into new media. If neonets (F3) has presented, the neonets (F3) devided from the previous media and count in different place to avoid the neonets (F3) growth up and difficult to be distinguished. The main research will be done if all of Daphnia (F2) died.

Growth rate, net reproduction rate, natality rate, mortality rate, and generation times will analyse using ANOVA with signigicatn degree $95 \%$. If the result has significant, the result will continued with Duncan test. Water quality will analyse with descriptive comparative. Water quality used for guideline point of research and take effect for life span Daphnia population.

\section{Result and Discussion}

The highest growth rate showed from quail manure (Table 1) with average amount 3,68 . The lowest growth rate showed from chicken manure treatment with average amount 2,32 . 
Table 1. Growth rate of daphnia sp. from culture

\begin{tabular}{llc}
\hline No & Treatment & $\begin{array}{c}\text { Growth Rate } \\
\text { (unit) }\end{array}$ \\
\hline 1 & Chicken manure & $2,32^{\mathrm{a}}$ \\
2 & Quail manure & $3,68^{\mathrm{b}}$ \\
3 & Cow manure & $2,74^{\mathrm{ab}}$ \\
4 & Goat manure & $2,55^{\mathrm{a}}$ \\
\hline
\end{tabular}

Note : The value follows by code of different word is not giving significant value according to Duncan double distance test in significant degree 95\%

The higest natality rate showed from quail manure amount 3,68 while the lowest natality rate showed from chicken manure with average 2,59.

Table 2. Natality rate of daphnia sp. from culture

\begin{tabular}{llc}
\hline No & Treatment & $\begin{array}{c}\text { Natality Rate } \\
\text { (unit) }\end{array}$ \\
\hline 1 & Chicken manure & $2,59^{\mathrm{a}}$ \\
2 & Quail manure & $3,87^{\mathrm{b}}$ \\
3 & Cow manure & $3,00^{\mathrm{a}}$ \\
4 & Goat manure & $3,31^{\mathrm{ab}}$ \\
\hline
\end{tabular}

Note: The value follows by code of different word is not giving significant value according to Duncan double distance test in significant degree 95\%

Mortality rate showed variant value from the research. The highest mortality rate showed from goat manure with average amount 0,76. The lowest mortality rate showed from quail manure with average amount 0,28.

Table 3. Mortality rate of daphnia sp. from culture

\begin{tabular}{llc}
\hline No & Treatment & $\begin{array}{c}\text { Mortality Rate Rate } \\
\text { (unit) }\end{array}$ \\
\hline 1 & Chicken & $0,28^{\mathrm{ab}}$ \\
2 & manure & $0,19^{\mathrm{b}}$ \\
3 & Cow mail manure & $0,26^{\mathrm{b}}$ \\
4 & Goat manure & $0,76^{\mathrm{a}}$ \\
\hline
\end{tabular}

Note : The value follows by code of different word is not giving significant value according to Duncan double distance test in significant degree 95\%
While the quail manure treatment give the highest of growth rate, natality rate, and low of mortality rate, but using quail manure give the lowest of maintenance time $(x)$. The maintenance time of using quail manure is lower than using another manure caused with high reproduction and decline the carying capacity of Daphnia sp. While the environtment in poor condition, Daphnia sp. will attend to growth, develop, and try to metabolism although the population will be decrease (Maier 2009).

Table 4. Generation times of daphnia sp. from culture

\begin{tabular}{lll}
\hline No & Treatment & $\begin{array}{c}\text { Generation } \\
\text { Times (days) }\end{array}$ \\
\hline 1 & Chicken manure & $2,87^{\mathrm{a}}$ \\
2 & Quail manure & $2,98^{\mathrm{ab}}$ \\
3 & Cow manure & $3,15^{\mathrm{b}}$ \\
4 & Goat manure & $2,88^{\mathrm{ab}}$ \\
\hline
\end{tabular}

Note: The value follows by code of different word is not giving significant value according to Duncan double distance test in significant degree 95\%

Cow manure give the higest generation time with average amount 3,15 days. This result showed very significant value than the others treatment. Quail manure give second position after cow manure. The lowest generation time showed from chicken manure with average value 2,87 days.

A new case showed in this research because cow manure showed the best perfomance of generation times. Bacteria to compose nitrogen compound from birds feces are more than mamals feces because bird change the compound twice, there are uric acid into urea, and urea into ammonia, while the mamals just change urea into ammonia. Feces from cow also contain fibre or selulose from their food (cow). It will make Daphnia difficult to filter and lost their food easily. Despite cow obtursive in generation times, quail manure showed high value in generation times although not as high cow, but quail manure consist give the best perform in every biological factor such as growth rate, natality rate, and mortality rate. From analysing the potential of Daphnia biological parameter with variant manure media (growth rate, natality rate, mortality rate, and generation time), quail manure fill all of the biological factor in good condition (Table 5). 
Table 5. Parameter test recapitulation

\begin{tabular}{lcccc}
\hline \multicolumn{1}{r}{ Treatment } & Growth rate & Natality rate & Mortality rate & Generation times \\
\hline Chicken manure & & & $\mathrm{X}$ & \\
Quail manure & $\mathbf{X}$ & $\mathbf{X}$ & $\mathbf{X}$ & $\mathbf{X}$ \\
Cow manure & $\mathrm{X}$ & & $\mathrm{X}$ & $\mathrm{X}$ \\
Goat manure & & $\mathrm{x}$ & & $\mathrm{X}$ \\
\hline
\end{tabular}

Table 6. Water quality of media culture

\begin{tabular}{lcccc}
\hline Manure Treatment & Temperature $\left({ }^{\circ} \mathbf{C}\right)$ & $\mathbf{D O}(\mathbf{m g} / \mathbf{l})$ & $\mathbf{p H}$ & $\mathbf{N H}_{3}(\mathbf{m g} / \mathbf{l})$ \\
\hline Chicken manure & $24,1-25,6$ & $3,7-4,2$ & $7,7-8,1$ & $0,08-0,15$ \\
Quail manure & $24,3-25,6$ & $3,6-4,1$ & $7,6-8,3$ & $0,10-0,38$ \\
Cow manure & $24,1-25,7$ & $3,7-4,2$ & $7,5-8,0$ & $0,01-0,13$ \\
Goat manure & $24,2-25,7$ & $3,7-4,2$ & $7,6-8,2$ & $0,01-0,13$ \\
\hline
\end{tabular}

Quail manure contain higher ammonia $(0,1-0,38 \mathrm{mg} / \mathrm{l})$ than another manure treatment. Ammonia is a key for this culture because the first product of animal waste is ammonia. Ammonia from chicken or poultry manure is from uric acid, and from mamals manure is from urea. Ammonia is very toxic for all organism, but in acid condition the toxicity will be decrease, so that $\mathrm{pH}$ monitoring is

Temperature on this research occur in tolerance range for Daphnia life span $\left(24,1^{\circ}\right.$ $25,7^{\circ} \mathrm{C}$ ). Khan and Khan (2008) said that if Daphnia will on optimum life span at $25^{\circ} \mathrm{C}$. Ocampo et al (2012) suggest the temperature for Daphnia culture amount $20-25^{\circ} \mathrm{C}$. Oxygen demand from culture media support respiration of Daphnia sp. without competition between Daphnia and decomposite microbial. DO in the culture controlled by aeration. DO in the media culture occur in tolerance range for Daphnia life span. Dapnia sp. could be life in DO $>3 \mathrm{mg} / \mathrm{l}$, but they growth up more optimum on $6 \mathrm{mg} / \mathrm{l}$ (Ocampo et al., 2012). Power of Hydrogen (pH) affected for eggs life span zooplankton microcrustacean (Vijverberg et al., 1996 in Darmawan 2014). According to Ocampo et al. (2012), optimumm pH for Daphnia culture on range $7-8,6$. Darmawan (2014) present that if neutral or on base relative (range $\mathrm{pH} 7,0-8,2$ ) is good for Daphnia magna growth. Power of hydrogen $(\mathrm{pH})$ determine the toxicity of medium from ammonia. According to Delzer and McKenzie (2003), nitrogen decomposition from ammonia, nitrit, and nitrat by microba start at 6 th day with temperature amount $20^{\circ} \mathrm{C}$. Normally,decomposition devided into two stages, carbonaceous (carbon decomposition start from 0 day), and nitrogenous (nitrogen decomposition). required for Daphnia culture. The example of ammonia decompocer in culture media are possibly-like grouped within Nitrosomonas and Nitrosococcus genus (Reddy and Shah, 2016). Daphnia sp. will eat them as non-selective filter feeder in culture media because Daphnia has potention to filter commensal and pathogenic bacteria associated with fecal pollution (Norgaard and Roslev 2016).

This research using manure soaked for three days. This time was not enaugh for ammonia decomposition, so that the consentration of ammonia in the treatments are $0,1-0,38 \mathrm{mg} / \mathrm{l}$. This concentration is deficient for Daphnia life span. Ammonia also influence the feeding rate according to Norgaard and Roslev (2016) with acute inhibition by unionized ammonia with a $24 \mathrm{~h}$ EC50 of $0,18 \mathrm{mg} / \mathrm{l}$ and a LOEC of $0,09 \mathrm{mg} / \mathrm{l}$.

\section{Conclution}

According to the result and discussion, cow manure give the best generation time followed with quail manure performed good of generation times. Quail manure manifested the best of biological factor includes generation times, growth rate, natality rate, and mortality rate in Daphnia culture than using chicken manure, goat manure, and cow manure.

\section{Acknowledgment}

Thanks to the Rector of Padjadjaran University for the Lecturers Research Internal grants scheme 2017. 


\section{References}

Celia, Y., R.S. Stemberger., B. Klaue., J. D. Blum., P.C. Pickhardt., C.L. Folt. 2000. Accumulation of Heavy Metals in Food Web Components Across a Gradient of Lakes. Limnology and Oceanography, 45 (7), 1525-1536.

Darmawan, J. 2014. Growth of Daphnia sp. Population in Culture Media with Catfish Culture Waste Water Addition (Clarias gariepinus Burchel 1822). Berita Biologi, 13 (1) April, 57 - 64 (In Bahasa).

Delzer, G.C., S.W. McKenzie. 2003. Five-Day Biochemical Oxygen Demand. USGS TWRI Book 9 - A7 (Third Edition).

Gillooly, J, F. 2000. Effect of Body Size and Temperature on Generation Time in Zooplankton. Plankton Research, 22 (2), 241-251.

Hamdani, H., Y. Andriani., A. Sahidin., T. Hidayat., T. Herawati. 2018. Culture of Daphnia sp. (Crustacean - Cladocera): The Effet of Manure Variation on the Growth, Natality, and Mortality. IOP Conferences Series : Earth and Environmental Science, 137, 01.

Khan Q., M. Khan. 2008. Effect of Temperature on Waterflea Daphnia magna (Crustacea: Cladocera). Respository Nature Precidings. University of Illinois Chicago.

Maier, R.M. 2009. Bacteria; Growth. Environmental Microbiology, Academic Press Inc.

Mansour, S.A. 2015. Toxicity of Some Pesticides, Heavy Metals, and Their Mixtures to Vibrio fischeri Bacteria and Daphnia magna: Comparative Study. Biology and Life Science 6 (2), 221 241.

Mubarak, A.Shofy., D.T.R Tias., L Sulmartiwi. 2009. Dolimit Addition in Daphnia sp. Culture in Daily Feeding System in Population of Daphnia and Water Quality Stability. Perikanan dan Kelautan, 1 (1), 67 - 73 (In Bahasa).

Norgaard, L.S., Roslev, P. 2016. Effect of Ammonia and Density on Filtering of Commensal and Pathogenic Escherichia coli by the Cladoceran Daphnia magna. Bull Environ Contam Toxicol, 97, 848 854. DOI 10.1007/s00128-016-1963-8.

Ocampo, L., M. Botero., L. F. Restrepo. 2012. Measurements Population Growth and Fecundity of Daphnia Magna to Different Levels of Nutrients Under Stress Condition. Intech Open; Aquaculture, Dr. Zainal Muchilisin (Ed). ISBN 978-953307-974-5.

Prastya, W., I, Dewiyanti., dan T, Ridwan. 2016. The Affected of Dose of Soybean Fermentation Addition with Yeast to Population Growth of Daphnia magna. Mahasiswa Kelautan dan Perikanan Unsyiah, 1 (1), 55-65 (In Bahasa).

Pietrzak, Barbara. 2011. Interclonal Differences in Age-Specific Performance in Daphnia magna. J. Limnol, 70 (2) Special Insert : $345-352$.

Reddy G.V., M. P. Shah. 2016. Microbial Diversity of Ammonia Oxidizing Bacteria through Waste Water Genomics. Applied Microbiology Open Acces, 2, 1, 110.

Shigang, Yu. 1985. Chapter 3: Pond Fertilization And Fish Feeds. Training Manual Integrated Fish Farming in China. Network of Aquaculture Centres In Asia: Bangkok. http://www.fao.org/ docrep/field/003/AC264E/AC264E03.htm

Sriyasak, P., C. Chitmanat., N. Whangchai., J. Promya., L. Lebel. 2015. Effect of Water De-Stratification on Dissolved Oxygen and Ammonia in Tilapia Ponds in Northern Thailand. Int Aqua Res, 7, 287 $-299$.

Weisse, Thomas. 2006. Freshwater ciliates as ecophysiological model organisms lessons from Daphnia. Major Achievements, and Future Perspectives. Arch Hydrobiol, 167 (1-4), 371 - 402.

Xiang, F., W. Yang., Y. Chen., Z. Yang. 2010. Acute Toxicity of Nitrite and Ammonia to Daphnia similoides of Different Developmental Stages: Using the Modified Gaussian Model to Describe. Bull Environ Contam Toxicol 84, 708711. DOI 10.1007/s00128-010-0017. 